Brit. J. industr. Med., 1965, 22, 220.

\title{
ORGANO-CHLORINE INSECTICIDE CONTENT OF HUMAN ADIPOSE TISSUE IN SOUTH-EASTERN ENGLAND
}

\author{
BY
}

\author{
J. ROBINSON, A. RICHARDSON, C. G. HUNTER, A. N. CRABTREE, and H. J. REES \\ From Shell Research Ltd., Tunstall Laboratory, Sittingbourne, Kent
}

(RECEIVED FOR PUBLICATION FEBRUARY 18, 1965)

\begin{abstract}
One hundred specimens of human body fat, 50 necropsy and 50 biopsy, were collected in 1964 from a semi-rural area in south-eastern England. The specimens were analysed by two methods and the concentrations of seven organo-chlorine insecticides were determined. The results of the two analytical methods were in good agreement. Endrin and heptachlor epoxide were not detected in any of the specimens analysed for these compounds. The average concentrations of lindane, $o p^{\prime}$-DDT, and $o p^{\prime}$-DDE were very small: 0.015 p.p.m., 0.03 p.p.m., and 0.02 p.p.m. respectively. The average concentration of HEOD in the 100 specimens of fat (no significant difference in the means of the necropsy and biopsy fats was detected) was 0.21 p.p.m., as in the 1961 survey. The average concentration of total equivalent-DDT (DDT + DDE) in the 50 necropsy fats was 3.9 p.p.m., as compared with $2 \cdot 2$ p.p.m. in 1961 . In the biopsy fats the average concentration for males was 4.9 p.p.m., and for females 3.4 p.p.m. One method was suitable for the separate determination of $p p^{\prime}-\mathrm{DDT}$ and $p p^{\prime}-\mathrm{DDE}$. The average concentration of $p p^{\prime}-\mathrm{DDT}$ was 1.0 p.p.m. in the 100 necropsy and biopsy fats. The average concentration of $p p^{\prime}-\mathrm{DDE}$ was $2 \cdot 2 \mathrm{p} . \mathrm{p} . \mathrm{m}$. in the 50 necropsy fats, and 3.1 p.p.m. and 2.0 p.p.m. in male and female biopsy fats respectively. The variability of the concentrations of these compounds in the necropsy specimens was generally greater than in the biopsy specimens. No significant differences were found which were attributable to age or to the cause of death. It is considered that the amounts found of these compounds do not constitute a hazard to the population sampled in this survey. The design of surveys to determine the concentrations of organo-chlorine insecticides in man is discussed.
\end{abstract}

Organo-chlorine insecticides may be classified, according to their chemical composition, into three groups: (a) diphenylethane derivatives, e.g., $p p^{\prime}$-DDT, $p p^{\prime}$-DDE, Rhothane, Methoxychlor, etc.; (b) the $\gamma$-isomer of hexachlorocyclohexane, and toxaphene, a chlorinated camphene; and (c) hexachloronorbornene derivatives, e.g., aldrin, dieldrin, endrin, heptachlor, etc.*

The various members of these groups of compounds possess varying propensities for storage in the body fat of experimental animals. The use of these insecticides in agriculture and public health, with the consequent potential exposure of man to the compounds, has prompted a number of investigations into the storage in man of, in particular, DDT and dieldrin. The presence of residues of these compounds in specimens of necropsy fat, obtained in 1961, has already been reported (Hunter, Robinson, and Richardson, 1963). In this paper the results of a second survey of specimens of human fat obtained in 1964 are reported. The primary intention was to obtain information on the changes, if any, in the concentrations in necropsy fats of DDT and dieldrin derived materials during the three-year period, but a product containing $85 \%$ of the compound $1,2,3,4,10,10$-hexachloro-6,7-epoxy$1,4,4 a, 5,6,7,8,8 \mathrm{a}$-octahydro-exo-1,4-endo5,8-dimethanonaphthalene (HEOD)

$1,2,3,4,10,10$-hexachloro-6,7-epoxy$1,4,4 \mathrm{a}, 5,6,7,8,8 \mathrm{a}-\mathrm{octah} y d r o-e x o-1,4-e x 0-5,8$ dimethanonaphthalene

1,4,5,6,7,10,10-heptachloro-4,7,8,9-tetrahydro-

$\begin{array}{ll}\text { heptachlor } & 1,4,5,6,7,10,10 \text {-heptachloro-4,7,8,9-tetrahydro- } \\ \text { heptachlor epoxide } & 1,4,7-6,7,10 \text {, }\end{array}$ hexahydro-4,7-methyleneindene
hethen 
the investigation has been extended to include biopsy fats and also the determination of the residues of other organo-chlorine insecticides. Specifically we have analysed the specimens of fat, both necropsy and biopsy, for the presence of $p p^{\prime}-\mathrm{DDT}, p p^{\prime}-\mathrm{DDE}$ (a metabolite of $p p^{\prime}$-DDT), $o p^{\prime}$-DDT (an isomer of $p p^{\prime}$-DDT present in the technical material), $\gamma$-BHC (lindane), heptachlor epoxide, endrin, and residues derived from the insecticides aldrin and dieldrin. Both the latter insecticides give rise to residues of a compound which is conveniently abbreviated to HEOD; HEOD is the major component of technical dieldrin and it is also a biochemical conversion product of the major component in technical aldrin.

\section{Materials and Methods}

Specimens of body fat were obtained from 50 consecutive necropsies of human subjects who died natural or accidental deaths in the same semi-rural area in southeastern England as that surveyed in 1961. In addition 50 specimens of subcutaneous or omental fat were obtained by laparotomy from hospital patients in the same rural area. All the patients were in a fair to good nutritional state. None of the persons from whom specimens were obtained had had any known occupational exposure to organo-chlorine insecticides. Of the 50 necropsy fats, 28 were from men and 21 from women; the sex of the remaining person was not reported to us. The samples of biopsy fats consisted of 23 specimens from men and 27 from women. The age distributions of the two groups of persons are shown in Figure 1. The causes of death, in the case of the necropsy specimens, were classified into four categories, and the numbers of fats corresponding to each of the categories are shown in Table 1.

Each fat was analysed by two different methods. One of these methods was the same as that used in the previous survey (Hunter et al., 1963), namely, alkaline hydrolysis of the fat followed by the determination of HEOD,
TABLE 1

CLASSIFICATION OF NECROPSY FATS BY CAUSE OF DEATH

\begin{tabular}{l|c|c}
\hline \multirow{1}{*}{ Cause of Death } & \multicolumn{2}{|c}{$\begin{array}{c}\text { Number of Deaths Corresponding to } \\
\text { the Specified Cause of Death }\end{array}$} \\
\cline { 2 - 3 } Neoplasms & Males & Females \\
\hline $\begin{array}{l}\text { Cardiovascular disease } \\
\text { includir.g kidney disease }\end{array}$ & 4 & 3 \\
Infections & 18 & 11 \\
Accidents & 3 & 3 \\
\hline
\end{tabular}

$p p^{\prime}$-DDE, and endrin in the unsaponifiable fraction by gas-liquid chromatography using an electron capture type detector. The column size was $92 \mathrm{~cm} . \times 0.4 \mathrm{~cm}$., the stationary phase liquid was Oronite-Polybutene $128,2 \%$ on silanized Celite, and the column temperature was $168^{\circ} \mathrm{C}$. The other analytical method did not involve a hydrolysis step and could therefore be used for the determination of alkali-unstable materials. An extract of the fat in redistilled light petroleum (b.p. $64-67^{\circ}$ ) was prepared, and the organo-chlorine compounds were extracted by shaking into dimethylformamide. These compounds were then re-extracted by light petroleum after an aqueous sodium sulphate solution had been added to the dimethylformamide. The hydrocarbon layer was separated from the aqueous phase, washed with distilled water, and dried with anhydrous sodium sulphate. The dried light petroleum extract was then run through a Florisil adsorption column and the organo-chlorine compounds were eluted with suitable solvent mixtures. The eluates were then injected into a gas-liquid chromatographic apparatus fitted with an electron capture detector. The column conditions were the same as those used in the hydrolytic method. Using this technique it is possible to determine $\gamma$-BHC, heptachlor epoxide, aldrin and dieldrinderived material (HEOD), endrin, $p p^{\prime}$-DDE, $p p^{\prime}$-DDT, $o p^{\prime}$-DDT, and $p p^{\prime}$-DDD. Considerable difficulty was
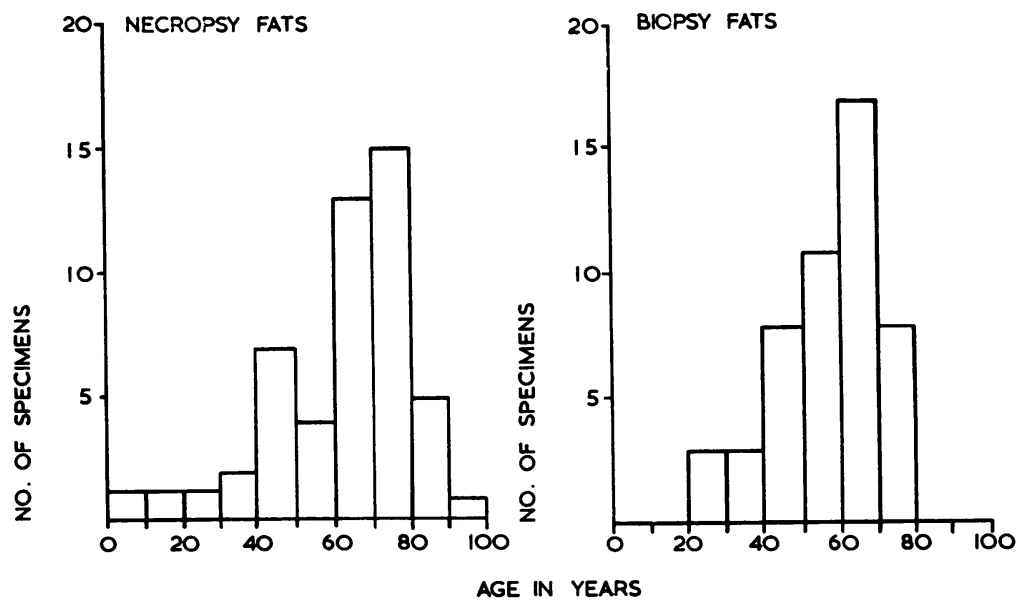

FIG. 1.-Age distribution of persons from whom specimens of fat were obtained. 
experienced in the determination of $p p^{\prime}$-DDT as a result of its instability in the gas-liquid chromatographic conditions used; this instability appears to be mainly the result of catalytic breakdown. Glass columns and glasslined injection ports were used, and the temperature was the minimum compatible with an acceptable retention time. The performance of the columns deteriorated with use: artefacts were produced which simulated $o p^{\prime}-$-DDT as regards retention time, with a consequent reduction in the apparent $p p^{\prime}$-DDT content. It was found necessary to change the columns frequently to ensure that reliable $p p^{\prime}$-DDT results were obtained. Full details of these analytical techniques will be published elsewhere. The extractable lipids were determined in about half the fats by taking an aliquot of the light petroleum extract, evaporating the solvent, and weighing the residue.

\section{Results}

The concentrations of organo-chlorine insecticides determined by the two methods are summarized in the form of histograms. Figure 2 gives the concentration distribution for HEOD by the two analytical methods, and Fig. 3 gives the distribution of total equivalent-DDT. In Fig. 4 the results obtained for $p p^{\prime}-\mathrm{DDT}$ and $p p^{\prime}$-DDE respectively are summarized. A number of the specimens of fat were also analysed for $\gamma$-BHC (lindane), endrin, heptachlor epoxide, and for the $o p^{\prime}$-isomer of DDT; the results are given in Table 2. The concentrations of extractable lipid determined in some of the specimens are shown in the histogram in Figure 5.
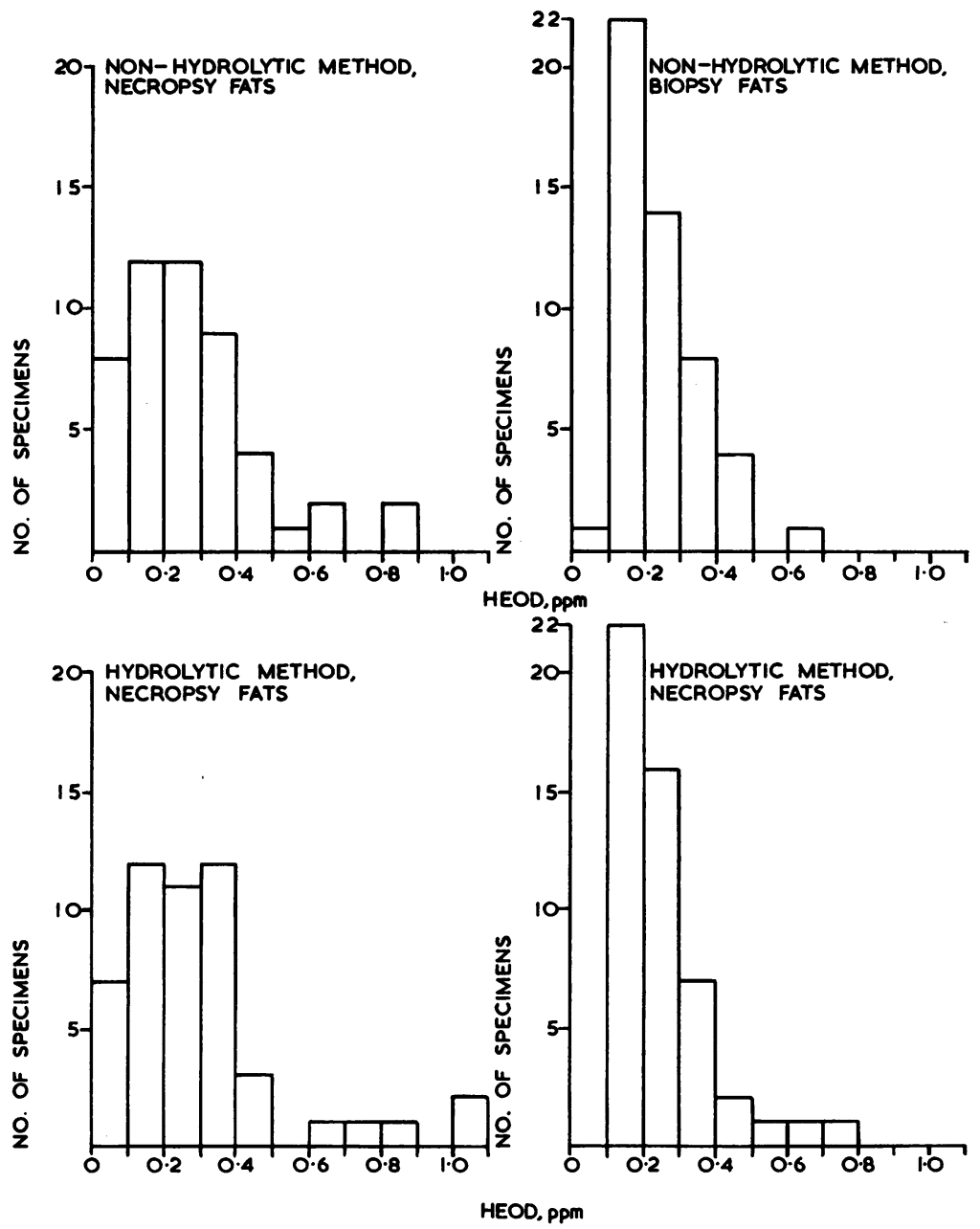

FIG. 2.-Concentration of HEOD in specimens of human fat. 

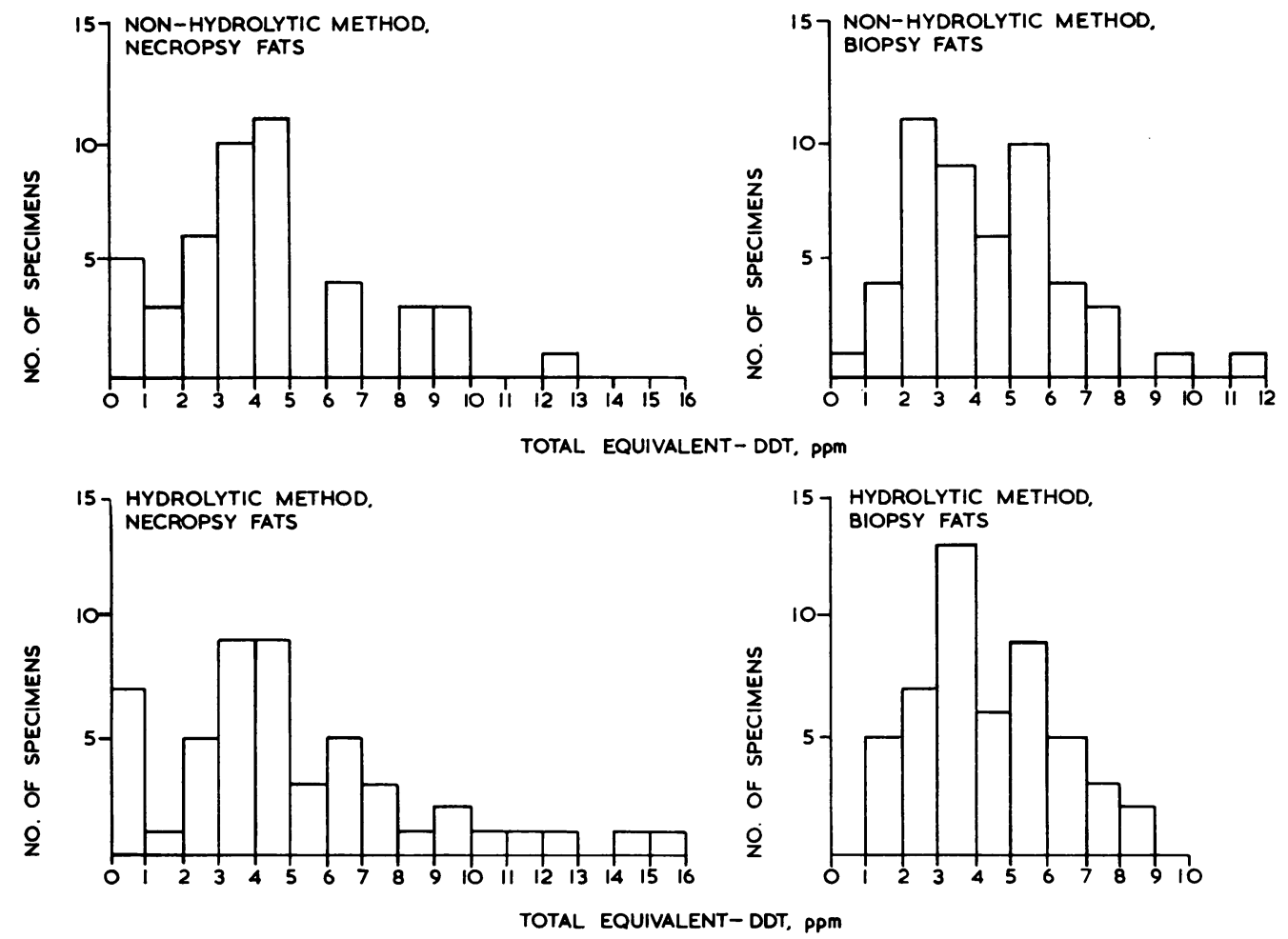

FIG. 3.-Total equivalent-DDT in specimens of human fat.

\section{Discussion}

Comparison of Analytical Techniques.-Two analytical methods were used for the determination of HEOD and equivalent-DDT. These methods are not completely independent in that both include a final step using gas-liquid chromatographic equipment with an electron capture detector. However, the clean-up procedures before injection into the gas chromatographic equipment are quite different, and the concordance of the results of the two methods is a measure of the validity of the methods in respect of the identity of the components. The concordance is good considering the low levels found (Table 3), and the overall picture of the distribution of the compounds between the specimens of fat can be accepted with confidence. The amounts of HEOD estimated by the two methods may differ because of the presence of $o p^{\prime}$-DDE and $p p^{\prime}$-dehydrochlorinatedDDD, neither of which would be completely separated from HEOD in the hydrolytic method. They would not, however, interfere in the non-hydrolytic method.
Comparison of Organo-Chlorine Insecticide Residues in Various Specimens of Human Fat.-As the analytical results appear to be generally trustworthy their implications can be discussed. The results obtained by the alkaline hydrolysis technique will be used unless otherwise stated.

Before examining the results for the human fats it is helpful to summarize the conclusions which may be drawn from investigations with experimental animals. These conclusions are as follows. The concentration of an organo-chlorine insecticide in the body fat of an animal is a function, firstly, of the amount of the compound in the food of the animal; secondly, of the period of exposure to the insecticidecontaining diet; thirdly, of the dynamic equilibrium between the blood and tissues as measured by the partition coefficients between them; and fourthly, of the rate of elimination of the compound. There is often a tendency for the concentration in the fat of female animals to differ from that in male animals. Finally, there are considerable variations between animals of the same sex even when the exposure is constant. But for a given animal the amount in the 

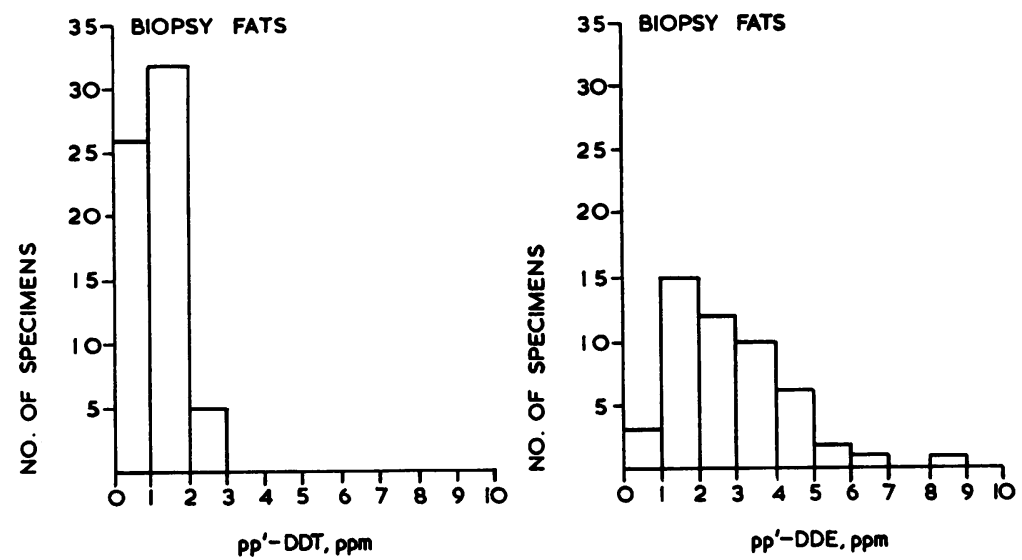

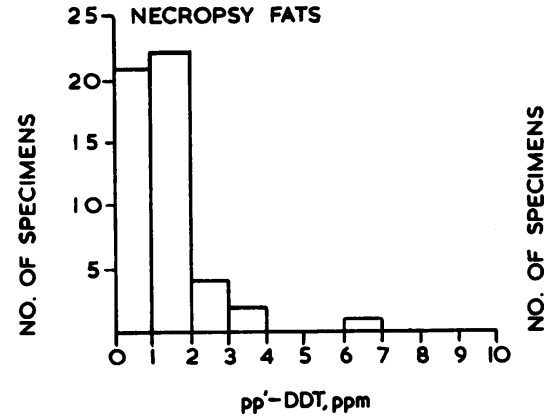

TABLE 2

CONCENTRATIONS OF LINDANE, ENDRIN, HEPTACHLOR EPOXIDE, AND op'-DDT IN SPECIMENS OF HUMAN FAT

\begin{tabular}{l|c|c}
\hline Insecticide & $\begin{array}{c}\text { No. of } \\
\text { Specimens } \\
\text { Analysed }\end{array}$ & $\begin{array}{c}\text { Mean (arithmetic) Concentration of } \\
\text { Insecticide (p.p.m.; range of } \\
\text { observations) }\end{array}$ \\
\hline $\begin{array}{c}\text { Lindane } \\
(\gamma-\mathrm{BHC})\end{array}$ & 20 & $0.015(<0.002-0.03)$ \\
$\begin{array}{l}\text { Endrin } \\
\begin{array}{l}\text { Heptachlor } \\
\text { epoxide }\end{array}\end{array}$ & 91 & $<0.02^{*}$ \\
op'-DDT & 20 & $<0.01^{*}$ \\
$o p^{\prime}-\mathrm{DDE}$ & 20 & $0.03(<0.02-0.050)$ \\
\hline
\end{tabular}

*Less than experimental limits of detection.

fat is proportional to the amount in the food within the experimental error; and the relation between the concentration in the fat and the period of exposure to the diet appears to be of the asymptotic type, i.e., a steady level is finally reached when intake equals excretion. This has been fully established for HEOD by Ludwig, Weis, and Korte (1964). It is also
Fig. 4.-Concentration of $p p^{\prime}$-DDT and $p p^{\prime}$-DDE in specimens of human fat.

generally compatible with the experimental results for rats, dogs, sheep, and monkeys although unequivocal proof for the attainment of a steady state has not been obtained for all the organochlorine insecticides in all the species. The finding that the concentrations in fat do not increase continually when animals are subjected to constant exposure is of obvious importance.

It must be remembered, however, in attempting to extrapolate the results of animal experiments to man

TABLE 3

AVERAGE CONCENTRATIONS OF HEOD AND TOTAL EQUIVALENT-DDT IN SPECIMENS OF HUMAN FAT

\begin{tabular}{|c|c|c|c|c|}
\hline \multirow{3}{*}{$\begin{array}{l}\text { Extraction } \\
\text { Technique }\end{array}$} & \multicolumn{4}{|c|}{$\begin{array}{l}\text { Mean (arithmetic) Concentrations of } \\
\text { Organo-chlorine Insecticide (p.p.m.) }\end{array}$} \\
\hline & \multicolumn{2}{|c|}{ Necropsy Fats } & \multicolumn{2}{|c|}{ Biopsy Fats } \\
\hline & HEOD & $\begin{array}{c}\text { Total } \\
\text { Equivalent- } \\
\text { DDT }\end{array}$ & HEOD & $\begin{array}{c}\text { Total } \\
\text { Equivalent- } \\
\text { DDT }\end{array}$ \\
\hline Alkaline hydrolysis & $0 \cdot 28$ & $5 \cdot 2$ & 0.25 & $4 \cdot 5$ \\
\hline Non-hydrolysis & $0 \cdot 26$ & $4 \cdot 5$ & 0.25 & $4 \cdot 5$ \\
\hline
\end{tabular}




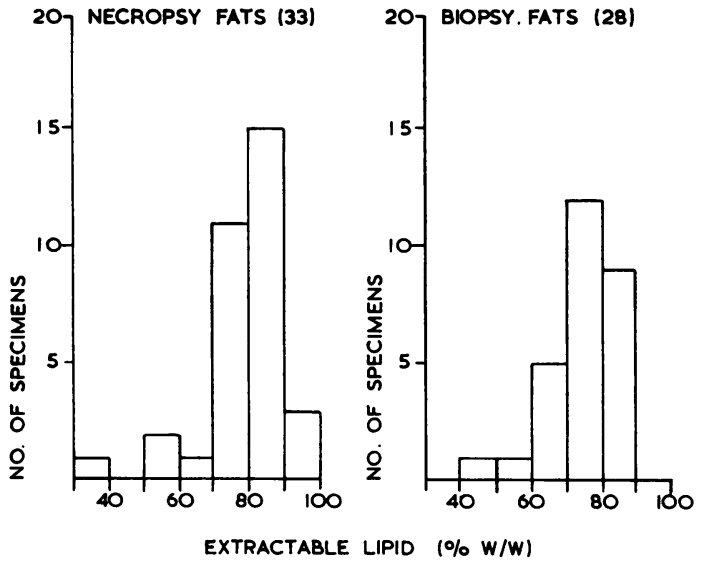

FIG. 5.-Concentrations of extractable lipid in specimens of human fat.

that there are a number of differences between the conditions of animal experiments and those prevailing in the case of man. In particular, the exposure of the animals is as uniform as possible and the environment of the animals is usually closely controlled. In man, his potential exposure varies as regards both quantity and form. The distribution of residues in the human diet is not uniform. It may vary from one type of food to another and also from one season of the year to another, and in addition non-dietary exposure may be occurring. Again, man's physical environment is more variable. These differences in exposure between persons, combined with the differences between persons in the dynamics of uptake, distribution, and elimination of organo-chlorine insecticides will result in considerable variations in the concentrations of these compounds in the body fat of different persons, a conclusion which is in accordance with the observed variation in residues (see Figs 2, 3, and 4).

The persons from whom the specimens were obtained differed in regard to sex, age, extractable lipid content, dietary intake, nutritional status, and, in the case of the necropsy fats, the cause of death. The possibility that the concentrations of organo-chlorine insecticides in the specimens of human fat are related, causally or otherwise, to these variables cannot be excluded on a-priori grounds. In attempting to isolate the effects of these variables, the number of specimens in the corresponding sub-sets becomes quite small, and this limitation must be borne in mind when it is inferred that a given variable has no significant effect on the concentration of organochlorine compounds in the body fat. However, an examination of the results (by the Spearman rank correlation technique) for correlations between the concentration of HEOD or total equivalent-DDT and the age of the person from whom the body fat was obtained indicated that the concentration did not depend on age or, in the case of necropy fats, on cause of death, classified as in Table 1. The extractable lipid contents of the necropsy and biopsy fats were not significantly different, and no significant correlations were found between the concentration of the insecticides and the concentrations of lipid in the specimens of fat. It was concluded, therefore, that the 100 specimens of fat could be classified into four groups, namely, male or female necropsy fats and male or female biopsy fats. In the analysis of variance of the necropsy fats classified according to cause of death it was found that the variances of each group were different. Furthermore, the concentrations of HEOD etc. found were obviously not distributed symmetrically about their averages, i.e., the distributions were skew with a lot of low values but a few relatively high ones. Statistical analysis confirms that these distributions are skew, and in such cases it is usual to carry out statistical tests in terms of the logarithms of the concentrations. The logarithms are normally distributed, and comparisons between the geometric means can be made by the standard statistical methods.

HEOD, Distribution in Necropsy and Biopsy Fats.-The geometric means of the necropsy fats of male and female origin are not significantly different, neither are the corresponding means of the biopsy fats. In the latter, however, the variance of the specimens of female fat is significantly higher $(P=0.025)$ than that of the male fats. A comparison of the results for necropsy and biopsy fats showed that the geometric means are not significantly different for either the male or female fats, but that the variance of the necropsy specimens is significantly greater than that of the biopsy fats in the case of males $(P=<0.001)$ though not in that of females. The statistical analysis for HEOD residues is summarized in Table 4.

The significantly higher variance of male necropsy fats as compared with that of the biopsy fats appears to indicate that the process of dying has an effect on the concentration of HEOD in the body fat of males. This effect appears to be independent of age at death since, as pointed out above, age and HEOD concentration are not related. Why the variances of the female necropsy and biopsy fats are not significantly different is obscure.

The results obtained from the necropsy fats, male and female, have been pooled for comparison with the results from the specimens obtained in 1961 (Hunter et al., 1963). No significant difference in mean values or variance between the two sets of 
TABLE 4

CONCENTRATION OF HEOD IN NECROPSY AND BIOPSY FATS: STATISTICAL ANALYSIS

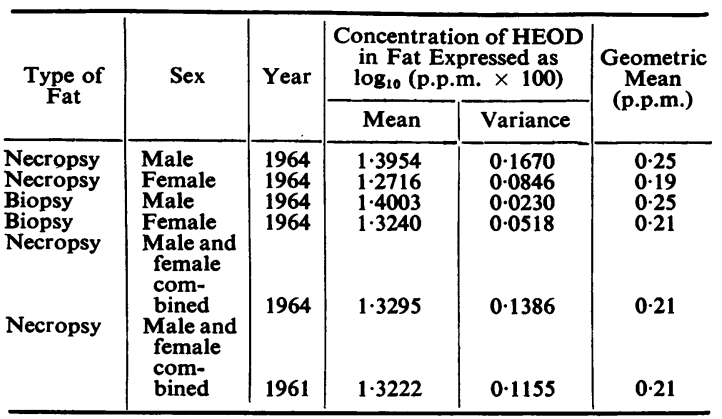

results was detected. This conclusion is of great importance. It implies that in the population surveyed the intake and elimination of dieldrin (and/or aldrin) had reached a state of balance by 1961 , and that the daily intake has not changed significantly since then. Factors other than these may, of course, be involved.

It is interesting to compare the results of the surveys in the United Kingdom with those of the United States, the only other country for which information has been published; these are summarized in Table 5.

TABLE 5

CONCENTRATION OF HEOD IN HUMAN FAT COMPARISON OF U.K. AND U.S.A. SAMPLES

\begin{tabular}{|c|c|c|c|c|}
\hline Country & Year & $\begin{array}{c}\text { No. of } \\
\text { Specimens }\end{array}$ & $\begin{array}{l}\text { Mean } \\
\text { HEOD } \\
\text { Content } \\
\text { (p.p.m.) }\end{array}$ & Reference \\
\hline $\begin{array}{l}\text { U.K. } \\
\text { U.K. } \\
\text { U.S.A. } \\
\text { U.S.A. }\end{array}$ & $\begin{array}{c}1961 \\
1964 \\
1961 / 2 \\
1962 / 3\end{array}$ & $\begin{array}{r}131 \\
100 \\
28 \\
64\end{array}$ & $\begin{array}{l}0.21^{*} \\
0.21^{*} \\
0.08^{*} \\
0.11 \dagger\end{array}$ & $\begin{array}{l}\text { Hunter et al. (1963) } \\
\text { This communication } \\
\text { Dale \& Quinby (1963) } \\
\text { Hoffman et al. (1964) }\end{array}$ \\
\hline
\end{tabular}

* Geometric mean; $\uparrow$ arithmetic mean.

The specimens of human fat analysed in the 1961/2 survey (Dale and Quinby, 1963) were obtained from three different areas of the United States of America. One of the areas (Louisville, Kentucky) gave results which are significantly lower than those for the other areas. For the other two (Wenatchee, Washington and Phoenix, Arizona) the geometric means, 0.15, are not significantly different from those obtained in the two United Kingdom surveys in 1961 and 1964. The results of the survey in 1962/3 (Hoffman, Fishbein, Andelman, 1964) are similar to those for other surveys in the U.K. and U.S.A. but sufficient information is not available for detailed comparisons to be made. It is also noteworthy that the results for the two U.S. surveys appear, as in the case of the U.K. surveys, to have positively skew distribution.

Total Equivalent-DDT, Distribution in Necropsy and Biopsy Fats.-A comparison of the results for necropsy fats from male and female subjects shows that the geometric means are not significantly different, whereas for biopsy fats the mean concentration in males is significantly higher than that in females. Necropsy and biopsy fats do not differ significantly as regards the mean content of total equivalent-DDT for either males or females, but the variances of the necropsy fats, both male and female, are significantly greater than those of biopsy fats. These results are summarized in Table 6.

TABLE 6

CONCENTRATION OF TOTAL EQUIVALENT-DDT IN NECROPSY AND BIOPSY FATS: STATISTICAL ANALYSIS

\begin{tabular}{|c|c|c|c|c|c|}
\hline \multirow[t]{2}{*}{$\begin{array}{c}\text { Type of } \\
\text { Fat }\end{array}$} & \multirow[t]{2}{*}{$\begin{array}{l}\text { Sex of } \\
\text { Person }\end{array}$} & \multirow[t]{2}{*}{ Year } & \multicolumn{2}{|c|}{$\begin{array}{c}\text { Concentration of Total } \\
\text { Equivalent-DDT in Fat } \\
\text { Expressed as } \\
\log _{10}(\text { p.p.m. } \times 10)\end{array}$} & \multirow[t]{2}{*}{$\underset{\text { Mean }}{\text { Geometric }}$} \\
\hline & & & Mean & Variance & \\
\hline $\begin{array}{l}\text { Necropsy } \\
\text { Necropsy } \\
\text { Biopsy } \\
\text { Biopsy } \\
\text { Necropsy }\end{array}$ & $\begin{array}{l}\text { Male } \\
\text { Female } \\
\text { Male } \\
\text { Female } \\
\text { Male and } \\
\text { female } \\
\text { com- }\end{array}$ & $\begin{array}{l}1964 \\
1964 \\
1964 \\
1964\end{array}$ & $\begin{array}{l}1.6590 \\
1.5406 \\
1.6879 \\
1.5376\end{array}$ & $\begin{array}{l}0 \cdot 1963 \\
0 \cdot 1064 \\
0 \cdot 0301 \\
0 \cdot 0370\end{array}$ & $\begin{array}{l}4 \cdot 6 \\
3 \cdot 5 \\
4 \cdot 9 \\
3 \cdot 4\end{array}$ \\
\hline $\begin{array}{l}\text { Necropsy } \\
\text { Necropsy }\end{array}$ & $\begin{array}{l}\text { bined } \\
\text { Male and } \\
\text { female } \\
\text { Male and } \\
\text { female } \\
\text { com- } \\
\text { bined }\end{array}$ & 1964 & 1.5952 & $0 \cdot 1636$ & 3.9 \\
\hline
\end{tabular}

The mean results (male and female) for the necropsy fats in 1964 are significantly higher $(P=0.002)$ than for the 1961 samples. This significant increase in the concentration of DDTtype material in the three-year period warrants further investigation since it may be attributed to several causes. The most probable causes are either that the exposure of the population surveyed in 1961 and 1964 has increased in the three-year period, or that the exposure has remained fairly constant but the concentration in the body fat had not reached equilibrium in 1961. In either case we have no grounds for assuming that the concentration in human fat in this area of England in 1964 represents an equilibrium value; this can only be demonstrated by surveys in subsequent years.

The concentration of DDT-type materials in human fat has now been determined in a number of countries and the results are summarized in Table 7.

In our first paper attention was drawn to the significant correlation between the concentration of HEOD and total equivalent-DDT in the body fat. 
TABLE 7

CONCENTRATION OF TOTAL EQUIVALENT-DDT IN THE BODY FAT OF THE GENERAL POPULATION: COMPARISON BETWEEN DIFFERENT COUNTRIES AND YEARS

\begin{tabular}{|c|c|c|c|c|c|c|}
\hline Country & Year & $\begin{array}{c}\text { No. of } \\
\text { Specimens }\end{array}$ & Type of Specimens & $\mid \begin{array}{c}\text { Total } \\
\text { Equivalent- } \\
\text { DDT (p.p.m.) }\end{array}$ & Analytical Method & Reference \\
\hline U.S.A. & 1950 & 75 & Biopsy and necropsy & $5 \cdot 3 *$ & Schechter-Haller & Laug et al. (1951) \\
\hline U.S.A. & 1955 & 49 & Biopsy & $19 \cdot 9 *$ & Schechter-Haller & Hayes et al. (1956) \\
\hline U.S.A. & $1954-56$ & 61 & Biopsy and necropsy & $11 \cdot 7^{*}$ & Schechter-Haller & Hayes et al. (1958) \\
\hline U.S.A. & $1961-62$ & 117 & - & $12 \cdot 9^{*}$ & - & Quinby et al. (1963) \\
\hline U.S.A. & 1961-62 & 28 & Biopsy and necropsy & $10 \cdot 7^{*}$ & Schechter-Haller & Dale and Quinby (1963) \\
\hline U.S.A. & $1961-62$ & 28 & Biopsy and necropsy & $6 \cdot 7^{*}$ & $\begin{array}{l}\text { G.L.C. micro-coulometric } \\
\text { detector }\end{array}$ & Dale and Quinby (1963) \\
\hline U.S.A. & $1962-63$ & 282 & Necropsy & $11 \cdot 2^{*}$ & $\begin{array}{l}\text { G.L.C. micro-coulometric } \\
\text { detector }\end{array}$ & Hoffman et al. (1964) \\
\hline U.S.A. (Alaska) & 1960 & 20 & Biopsy & $3 \cdot 0^{*}$ & Schechter-Haller & Durham et al. (1961) \\
\hline U.S.A. & $1955-56$ & 16 & Biopsy (non-meat eaters) & $5 \cdot 9^{*}$ & Schechter-Haller & Hayes et al. (1958) \\
\hline Germany & $1958-59$ & 60 & Necropsy & $2 \cdot 3^{*}$ & Schechter-Haller & Maier-Bode (1960) \\
\hline Canada & $1959-60$ & 62 & Necropsy & $4 \cdot 9 *$ & Schechter-Haller & Read and McKinley (1961) \\
\hline France & 1961 & 10 & Necropsy & $5 \cdot 2^{*}$ & Schechter-Haller & Hayes et al. (1963) \\
\hline U.K. & $1961-62$ & 131 & Necropsy & $2 \cdot 2 \dagger$ & $\begin{array}{l}\text { G.L.C. electron capture } \\
\text { detector }\end{array}$ & Hunter et al. (1963) \\
\hline U.K. & 1964 & 100 & Biopsy and necropsy & $4 \cdot 0 \dagger$ & $\begin{array}{l}\text { G.L.C. electron capture } \\
\text { detector }\end{array}$ & This communication \\
\hline
\end{tabular}

* arithmetic mean; † geometric mean.

An examination of the results for this survey shows that the Spearman rank correlation coefficients HEOD/total equivalent-DDT for the necropsy fats is $0.53(\mathrm{P}=0.001)$; for male biopsy fats it is 0.34 (not significant); and for female biopsy fats 0.62 $(P=0.001)$. From the significant correlation obtained for the 1961 survey it was tentatively inferred that both HEOD and DDT had reached equilibrium levels. This hypothesis cannot be invoked to account for the significant correlations in the 1964 survey. The organo-chlorine insecticides tend to be concentrated in certain components of the diet (particularly the lipoidal constituents) and an alternative hypothesis is that the correlation is a reflection of the amounts and sources of the fatty foods eaten by any given person.

Distribution of $p p^{\prime}-D D T$ and $p p^{\prime}-D D E .-$ The concentrations of these compounds could only be determined by the non-hydrolytic technique using partition between dimethyl-formamide and elution through a Florisil column as the clean-up procedure before injection into the gas-liquid chromatographic equipment. The distribution of these compounds in the biopsy and necropsy samples is shown in Figure 4. No significant differences between the mean $p p^{\prime}$-DDT concentration of the male and female fats were found for either necropsy or biopsy specimens or between necropsy and biopsy specimens. The variances of the biopsy fats, however, were significantly less than those of the necropsy fats $(P=0.025$, males; and $P=0.05$, females). In the case of $p p^{\prime}-$ DDE the mean concentrations in the male samples, both biopsy and necropsy, were significantly greater than those in the female samples $(P=0.05$, necropsy $P<0.005$, biopsy). Once again the variances of the necropsy samples were significantly greater than those of the biopsy samples ( $P=0.025$, males and females). The results are summarized in Table 8.

A comparison of the results of this survey for the concentrations of $p p$-'DDT and $p p^{\prime}-\mathrm{DDE}$ in human fat and the results for surveys in other countries is given in Table 9.

The results of a survey of the DDT content of necropsy fats in Budapest have been summarized (Dénes, 1962). The ratio of the concentration of $p p^{\prime}$-DDE to that of $p p^{\prime}$-DDT shows some variation from one survey to another, but in all cases the concentration of $p p^{\prime}-\mathrm{DDE}$ is greater than that of $p p^{\prime}$-DDT. This is in contrast with the ratio obtained in trials in which volunteers were given daily doses of recrystallized or technical DDT, when the average ratio of DDE/DDT was about $\mathbf{0} \cdot \mathbf{2}$ (Hayes, Durham, and Cueto, 1956). It is possible therefore that the ratio found in the general population indicates that exposure to $p p^{\prime}-\mathrm{DDE}$ as well as to $p p^{\prime}-\mathrm{DDT}$ is 
TABLE 8

CONCENTRATION OF $p p^{\prime}$-DDT AND $p p^{\prime}$-DDE IN NECROPSY AND BIOPSY FATS COLLECTED IN 1964

\begin{tabular}{|c|c|c|c|c|c|c|c|}
\hline \multirow[t]{2}{*}{ Type of Fat } & \multirow[t]{2}{*}{ Sex } & \multicolumn{2}{|c|}{$\begin{array}{l}\text { Concentration of pp'-DDT } \\
\text { in Fat Expressed as } \\
\log _{10}(\text { p.p.m. } \times 10)\end{array}$} & \multirow{2}{*}{$\begin{array}{l}\text { pp'-DDT } \\
\text { (p.p.m.) } \\
\text { Geometric } \\
\text { Mean }\end{array}$} & \multicolumn{2}{|c|}{$\begin{array}{c}\text { Concentration of } p p^{\prime}-\mathrm{DDE} \\
\text { in Fat Expressed as } \\
\log _{10}(\mathrm{C} \times 10)\end{array}$} & \multirow{2}{*}{$\begin{array}{l}\text { pp'-DDE } \\
\text { (p.p.m.) } \\
\text { Geometric } \\
\text { Mean }\end{array}$} \\
\hline & & Mean & Variance & & Mean & Variance & \\
\hline Necropsy & $\mathbf{M}$ & $1 \cdot 0135$ & 0.1237 & 1.0 & $1 \cdot 3838$ & 0.1479 & $2 \cdot 4$ \\
\hline Necropsy & $\mathbf{F}$ & 0.9800 & $0 \cdot 1275$ & 1.0 & $1 \cdot 3154$ & 0.1098 & $2 \cdot 1$ \\
\hline Biopsy & $\mathbf{M}$ & $1 \cdot 0716$ & 0.0475 & $1 \cdot 2$ & 1.4983 & 0.0558 & $3 \cdot 1$ \\
\hline Biopsy & $\mathbf{F}$ & 1.0116 & 0.0575 & 1.0 & $1 \cdot 2981$ & 0.0470 & $2 \cdot 0$ \\
\hline
\end{tabular}

TABLE 9

CONCENTRATION OF $p p^{\prime}-$-DDT and $p p^{\prime}$-DDE IN THE BODY FAT OF THE GENERAL POPULATION: COMPARISON OF SURVEYS IN DIFFERENT COUNTRIES

\begin{tabular}{|c|c|c|c|c|c|}
\hline \multirow{2}{*}{ Country } & \multirow{2}{*}{ Year } & \multirow{2}{*}{$\begin{array}{c}\text { No. of } \\
\text { Specimens }\end{array}$} & \multicolumn{2}{|c|}{$\begin{array}{c}\text { Concentration } \\
\text { (p.p.m.) }\end{array}$} & \multirow{2}{*}{$\begin{array}{c}\text { Ratio } \\
p p^{\prime}-\mathrm{DDE} / \\
p p^{\prime}-\mathrm{DDT}\end{array}$} \\
\hline & & & $p p^{\prime}-\mathrm{DDT}$ & $p p^{\prime}-\mathrm{DDE}$ & \\
\hline \multirow{3}{*}{$\begin{array}{l}\text { U.S.A. } \\
\text { U.S.A. } \\
\text { U.S.A. } \\
\text { U.S.A. } \\
\text { U.S.A. } \\
\text { U.S.A. } \\
\text { U.S.A. } \\
\text { (Alaska) } \\
\text { U.S.A. (meat } \\
\text { abstainers) } \\
\text { Canada } \\
\text { Germany } \\
\text { France } \\
\text { U.K. }\end{array}$} & $\begin{array}{c}1950 \\
1955 \\
1954-56 \\
1961-62 \\
1961-62 \\
1962-63\end{array}$ & $\begin{array}{r}75 \\
49 \\
61 \\
117 \\
28 \\
282\end{array}$ & $\begin{array}{l}5 \cdot 3 \\
7 \cdot 4 \\
4 \cdot 9 \\
3 \cdot 4 \\
2 \cdot 4^{*} \\
2 \cdot 9\end{array}$ & $\begin{array}{r}1 \overline{11.2} \\
6.1 \\
8.1 \\
3.8 \\
7.4\end{array}$ & $\begin{array}{l}\overline{1.5} \\
1.2 \\
2.1 \\
1.6 \\
2.6\end{array}$ \\
\hline & 1960 & 20 & 0.8 & $2 \cdot 0$ & $2 \cdot 5$ \\
\hline & $\begin{array}{c}1955-63 \\
1959-60 \\
1958-59 \\
1961 \\
1964\end{array}$ & $\begin{array}{r}16 \\
62 \\
60 \\
10 \\
100\end{array}$ & $\begin{array}{l}2.3 \\
1.6 \\
1.0 \\
1.7 \\
1.0\end{array}$ & $\begin{array}{l}3 \cdot 2 \\
3 \cdot 0 \\
1 \cdot 2 \\
3 \cdot 1 \\
2 \cdot 3\end{array}$ & $\begin{array}{l}1.4 \\
1.9 \\
1.2 \\
1.8 \\
2.3\end{array}$ \\
\hline
\end{tabular}

*op'-DDT + pp'-DDT.

occurring. This inference is in accordance with the observed presence of $p p^{\prime}-\mathrm{DDE}$ in the human diet in the U.S.A. (Fischbach, 1962; Mills, 1963; Williams, 1964) and in the U.K. (Robinson, Richardson, and Bush, unpublished).

Residues of Other Organo-chlorine Insecticides in Human Fat.-Ninety-one of the specimens of fat were analysed for endrin. None was found in any of them (experimental limit of detection, 0.02 p.p.m.). Similarly, analysis of 20 specimens for heptachlor epoxide also failed to reveal any detectable amount of this compound (experimental limit of detection, 0.01 p.p.m.). The mean concentration of lindane in 20 specimens was 0.015 p.p.m. This is much lower than the concentrations found in two surveys in the U.S.A. in which the average concentrations were $\mathbf{0 . 2}$ and 0.6 p.p.m. lindane respectively (Dale and Quinby 1963; Hoffman et al., 1964). The average concentration of lindane in necropsy fats obtained in France was 1.2 p.p.m. (Hayes, Dale, and Le Breton, 1963).

Twenty specimens of fat were also analysed for $o p^{\prime}-\mathrm{DDT}$ and $o p^{\prime}-\mathrm{DDE}$. In both cases the concentrations found were near the experimental limits of detection, and the average concentrations were 0.03 and 0.02 p.p.m. respectively. These results should be regarded as only tentative since the identities of the compounds measured as $o p^{\prime}-\mathrm{DDT}$ and $o p^{\prime}-\mathrm{DDE}$ have not been confirmed by other techniques.

Toxicological Significance of the Residues of Organo-chlorine Insecticides.-Direct knowledge of the pharmacodynamic behaviour and toxicity of these compounds in man is meagre. The concentration of $p p^{\prime}$-DDT in the body fat of volunteers given daily doses (35 mg.) of this compound for periods of up to 18 months have been reported (Hayes et al., 1956). No ill-effects were found in any of the men. The average concentration of $p p^{\prime}-\mathrm{DDT}$ in the body fat was about 200 p.p.m. The study of men with occupational exposure to these compounds is also of assistance in interpreting the residues found in the general population. The body fat of agricultural workers in the U.S.A. was found to have an average content of 14 p.p.m. $p p^{\prime}$-DDT, and one man with extensive occupational exposure had 648 p.p.m. of $p p^{\prime}$-DDT in his body fat. These values, and also the average values obtained for the general population in the U.S.A. ( 2 to 7 p.p.m.), should be compared with the average value of 1 p.p.m. found in this survey of the population in a semi-rural area of south-eastern England.

In the case of dieldrin it has been found that occupationally exposed persons may have a concentration of HEOD in the blood which is some 30 times that of the general population. These workmen appear to be in a normal state of health. It has also been shown that the concentration of HEOD in the blood decreases when occupational exposure ceases. Specimens of body fat from two men working on an aldrin formulation plant contained 149 and 44 p.p.m. of HEOD respectively. This picture of increased body burden when the exposure increases, and loss from the body when the exposure is removed, indicates that there is no discontinuity between man and experimental animals in the pharmacodynamic behaviour of these compounds. 
Further, the comparison of the residues in the body fat of the general population with those in occupationally exposed persons, who have not suffered any apparent ill-effects as a result of their increased body burden, shows that the body burden of organochlorine insecticides in the general population is well below that at which harmful effects would be expected.

Design of Surveys to Determine Distribution of Organo-chlorine Insecticides in Man.- The concentrations of organo-chlorine insecticides in the body fat of man may be used, firstly, as an index of the body burden of these compounds and consequently of the hazard to the general population and, secondly, to enable us to follow the secular variations, if any, in the average body burden. There is also a third purpose served by these surveys. Two official enquiries ('Use of Pesticides', 1963; 'Review of Persistent Organo-chlorine Pesticides', 1964) have recommended that the accretion of persistent insecticides in the environment should be controlled. The occurrence of residues of these compounds in the general population is of adventitious origin and their concentration in human body fat therefore constitutes an index of the general environmental contamination. In view of these three uses of the results of surveys, it is essential that the design of surveys of insecticide residues in man should be such that valid conclusions can be drawn from results obtained by accurate and reliable analysis of the specimens of fat.

The statistical principles underlying the design of surveys is adequately discussed in standard statistical texts but it would be desirable to use the experience gained so far in insecticide residue surveys to improve, if necessary, the design of future surveys. It appears, for example, that significant differences may exist between the concentrations in the body fats of males and females, and that there may be differences between people in different geographical areas. The relationships between age and insecticide content of body fat, or between cause of death and insecticide content, appear to be non-significant in such investigations as have been made, but in view of the numbers of specimens involved it would be advisable to investigate these possibilities more fully. The significant difference between the variability of residues in necropsy and biopsy fats is perhaps relevant in this context. A further variable, which has not so far been investigated, is that of social class; the diets of the various social classes differ from one another, and there may be consequent differences in the body burdens of insecticides in persons of the different social classes. All these differences, observed or potential, emphasize the heterogeneity of the population being sampled in these surveys. If valid inferences are to be made concerning either the average body burden of the whole population of a country, or the changes in insecticide content with time, it is essential that the sampling schemes are suitably designed for such heterogeneous populations. The most suitable type of scheme, on the evidence available, appears to be stratified sampling, with perhaps proportional allocation for each of the strata. The characteristics for constructing the strata would be such variables as sex, geographical location, and/or social class etc. Once suitable strata have been chosen it is necessary to ensure that the fat specimens (or other tissues) selected for analysis are representative of the various strata. Unless the sampling scheme is so designed it will be difficult, particularly in the case of specimens collected at various times, to draw conclusions regarding the population as a whole and the significance of secular changes.

We express our gratitude to Mr. R. L. Canney and to Dr. G. B. Forbes for their interest and assistance in this survey.

\section{REFERENCES}

Dale, W. E., and Quinby, G. E. (1963). Science, 142, 593.

Dénes, A. (1962). Nahrung, 6, 48.

Durham, W. F., Armstrong, J. F., Upholt, W. M., and Heller, C. (1961). Science, 134, 1880.

Fischbach, H. (1962). Symposium of the Food Protection Committee. Washington.

Hayes, W. J., Jr., Durham, W. F., and Cueto, C., Jr. (1956). J. Amer. med. Ass., 162, 890

Quinby, G. E., Walker, K. C., Elliott, J. W., and Upholt, W. M. (1958). Arch. industr. Hith, 18, 398.

Dale, W. E., and LeBreton, R. (1963). Nature (Lond.), 199 1189.

Hoffman, W. S., Fishbein, W. I., and Andelman, M. B. (1964). Arch. environm. Hlth, 9, 387

Hunter, C. G., Robinson, J., and Richardson, A. (1963). Brit. med. J., i, 221.

Laug, E. P., Kunze, F. M., and Prickett, C. S. (1951). Arch. industr. Hyg., 3, 245

Ludwig, G., Weis, J., and Korte, F. (1964). Life Sciences, 3, 123

Maier-Bode, H. (1960). Med. exp. (Basel), 1, 146.

Mills, P. A. (1963). J. Ass. agric. Chem., 46, 762.

Quinby, G. E., Hayes, W. J., Jr., and Durham, W. F. (1963). (In preparation.) Quoted by Hayes and others.

Read, S. T., and McKinley, W. P. (1961). Arch. environm. Hlth, 3, 209.

Review of Persistent Organo-chlorine Pesticides. H.M. Stationery Office, London, 1964

Robinson, J., Richardson, A., and Bush, B. Unpublished work.

Use of Pesticides. Report of the President's Science Advisory Committee, Washington, 1963.

Williams, S. (1964). J. Ass. official agric. Chem., 47, 815. 